\title{
HEMOSTATIC EFFECT OF ETHANOL EXTRACT OF Piper betle, Linn LEAVES TO MALE MICE
}

\section{EFEK HEMOSTATIK EKSTRAK ETANOL DAUN SIRIH HIJAU (Piper betle, Linn) PADA MENCIT JANTAN}

\author{
Sadakata Sinulingga ${ }^{1}$, Subandrate ${ }^{1^{*}}$, Bebbi Arisya Kesumaputri ${ }^{2}$, Galuh Anggraini ${ }^{3}$ \\ ${ }^{1}$ Department of Biochemistery, Medical Faculty, Sriwijaya University \\ ${ }^{2}$ Dentist Program, Medical Faculty, Sriwijaya University \\ ${ }^{3}$ Dentist Program, Medical Faculty, Sriwijaya University/RSMH Palembang \\ *email: subandrate@unsri.ac.id
}

Received January 12, 2017; Accepted May 10, 2017; Available online May 30, 2017

\begin{abstract}
Hemorrhage occurs in most of the dental care. Untreated hemorrhage could cause excessive blood loss, hypotension, and cyanosis. A Natural resource that reported has an hemostatic effect is ethanol extract of betel leaves (Piper betel, Linn).The aim of this study is to find the minimum concentration of ethanol extract of betel leaves which capable of shortening the bleeding time in mice. The experimental study used pretestposttest with control group design was conducted on 35 mice that divided into 7 group which are negative control, positive control (feracrylum 1\%), the ethanol extract of betel leaves 1\%, 5\%, 10\%, 15\%, and $20 \%$. All mice were injected heparin intravenously. Mice's tail was cut at diameter $3 \mathrm{~mm}$ and pretest bleeding time was counted. Mice's tail was recut at diameter $4 \mathrm{~mm}$, given treatment for 5 seconds and posttest bleeding time was counted. Results of paired t-test showed that reduction of bleeding time between pretest and posttest was significant $(\mathrm{p}<0,050)$. The enhancement of ethanol extract of betel leaves concentration leads to better hemostatic effect. Results of ANOVA test showed that comparison of posttest bleeding time among groups was significant $(p<0,050)$. The minimum concentration of ethanol extract of betel leaves which capable of shortening the bleeding time in mice is $5 \%$.
\end{abstract}

Keywords: bleeding, bleeding time, dental care, the ethanol extract of betel leaves.

\section{ABSTRAK}

Perdarahan terjadi pada sebagian besar perawatan gigi. Perdarahan yang tidak ditangani dapat menyebabkan terjadinya kehilangan darah yang berlebihan, hipotensi, dan sianosis.Bahan alami yang dilaporkan memiliki efek hemostatik adalah ekstrak etanol daun sirih hijau (Piper betle, Linn).Penelitian ini bertujuan mengetahui konsentrasi minimal ekstrak etanol daun sirih hijau yang dapat memperpendek waktu perdarahan mencit.Penelitian ini bersifat eksperimental dengan pretest-posttest control group designmenggunakan 35 ekor mencit yang dibagi dalam 7 kelompok, yaitu kelompok kontrol negatif, kontrol positif (feracrylum 1\%), ekstrak etanol daun sirih hijau 1\%, 5\%, 10\%, 15\%, dan 20\%. Semua mencit diinjeksi heparin intravena.Kemudian ekor mencit dipotong pada diameter $3 \mathrm{~mm}$ dan dihitung waktu perdarahan sebelum perlakuan. Ekor mencit dipotong kembali pada diameter $4 \mathrm{~mm}$, diberikan perlakuan selama 5 detik, dan dihitung waktu perdarahan setelah perlakuan menggunakan stopwatch.Hasil uji t berpasangan waktu perdarahan sebelum dan sesudah perlakuan menunjukkan penurunan signifikan $(\mathrm{p}<0,05)$.Semakin tinggi konsentrasi ekstrak etanol daun sirih hijau, maka efek hemostatik semakin baik.Hasil uji ANOVA menunjukkan bahwa perbandingan rata-rata waktu perdarahan antar kelompok setelah perlakuan signifikan $(\mathrm{p}<0,05)$. Konsentrasi minimal ekstrak etanol daun sirih hijauyang dapat memperpendek waktu perdarahan mencit adalah $5 \%$.

Kata Kunci: ekstrak etanol daun sirih hijau, perawatan gigi, perdarahan, waktu perdarahan.

\section{INTRODUCTION}

Hemorrhage is a discharge of blood from the wounds or abnormalities in the blood vessels (Borle, 2014). Hemorrhage occurs in most of the dental care, such as tooth extraction, scaling, and gingivectomy. Hemorrhage that occurs in areas of the teeth and mouth will not quickly stop because this area has always been active, such as during speech and mastication (Borle, 2014). Mild hemorrhage occurred in $88.6 \%$ of all cases of dental care and did not require special treatment while severe hemorrhage occurred in $11.4 \%$ of all cases of dental care (Borle, 2014). Untreated hemorrhage could cause excessive blood loss, hypotension, and 
cyanosis of the lips and nail area (Sam, 2008; Borle, 2014).

Hemostasis is the cessation of hemorrhage after vascular injury (Sam, 2008; Borle, 2014). Hemorrhage can be stopped in several ways, such as given an adequate pressure using sterile gauze on the injured area and applied a sterile gauze that has been given Feracrylum 1\% directly on the injured area with an adequate pressure (Sam, 2008; Lahoti, Aggarwal, Shashi \& Laddha, 2010).

Natural resources that can be used to stop the hemorrhage is betel leaves. Empirically, people uses betel leaves (Piper betle, Linn) to stop the hemorrhage, such as gum's hemorrhage and epistaxis (Bissa, Songara, \& Bohra, 2007). In addition, people uses betel leaves to improve blood circulation, treatment of vaginal discharge, ulcers, hemorrhoids, toothache, bad breath, oral ulceration, body odor remover, cough drops, mouthwash, acne medication, antiseptic burns, eye drops, and reducing milk production (Bissa et al., 2007; Periyanayagam, Jagadeesan, Kavimani \& Vetriselvan, 2012; Bhalerao et al., 2013). Betel leaves contain water, protein, carbohydrates, minerals, fats, fiber, essential oil, tannins, saponins and flavonoids (Rupa, Banik, \& Jayanta, 2013). The ability of betel leaves to stop hemorrhage because it is contained tannins and saponins (Bele, Jadhav \& Kadam, 2010; Ashok \& Upadhyaya, 2012). Phytochemical test conducted by Nirmala \& Kumari (2015) states that betel leaves extract that diluted with ethanol contained tannins and saponins. Mechanism of action of tannins and saponins to stop the hemorrhage is through astringent effect (Bele et al., 2010). Tannins and saponins cause local vasoconstriction of the capillaries and increases platelet aggregation that induced hemostasis (Bele et al., 2010; Ashok et al., 2012).

In vitro studies conducted by Chakraborty (2011) states that $0.001 \%$ ethanol extract of betel leaves proved to have an effect of antihemolytic. In vivo study conducted by Tedjasulaksana (2013) states that $100 \%$ ethanol extract of betel leaves can shorten the bleeding time of mice.

Prior studies have examined the hemostatic effects of betel leaves, but have not reported the minimum concentration of ethanol extract of green betel leaf which can shorten the bleeding time. So this study was conducted to determine how much concentration of ethanol extract of green betel leaves which can shorten the bleeding time. This study conducted in mice (Mus musculus) as experimental animals based on the estimated size of the capillary blood vessels in mice which were the same as the size of the capillary blood vessels of human teeth (Grace, 2010).

\section{MATERIALS AND METHODS}

This study was an experimental laboratory in vivo. The study was completely randomized pre-test and post-test only control group design. The research was conducted in January-November 2016. The research was conducted at the Laboratory of Biochemistry and Animal House of the Medical Faculty of Sriwijaya University after obtaining approval from Bioethics and Humanities Unit of Medical Faculty of Sriwijaya University/RSMH Palembang no. 037/kepkrsmhfkUnsri/ 2016.

\section{Tools and materials}

The tools used in this study are cages of mice, bottled drinks, bottles for containers extract labeled, filter paper, digital scales, flask, evaporator, rubber gloves, fabric gloves, water bath, vortex, surgical tools minor, stopwatch and other tools that are used as needed. Materials used in this research are mice pellets (food base), betel leaves, 96\% ethanol, distilled water, alcohol $70 \%$, and $1 \%$ NaCMC solution.

\section{Research subject}

This research conducted in animal models, which is mice (Mus musculus) with the inclusion criteria: male sex; age three months; 20-22 grams weight and exclusion criteria: physical disability; mice looked sick and did not move on. The object of this study is betel leaves (Piper betle, Linn) is young and fresh. Researchers planted betel leaves himself in Bukit Sejahtera's Housing, Bukit Lama, Palembang.

\section{Research procedure Manufacture betel leaves extract}

Betel leaves extract made by maceration process. $1 \mathrm{~kg}$ of fresh betel leaves washed, drained, sliced, and dried in the sun indirectly. Sliced betel leaves are crushed using a blender to the obtains betel leaves powder. After that, betel leaves powder 
soaked into $1000 \mathrm{ml}$ of $96 \%$ ethanol for 72 hours and then filtered to obtain a filtrate. Then, the filtrate is evaporated using a rotary vacuum evaporator at $40^{\circ} \mathrm{C}$ for 3-4 hours so that the extract becomes thick. The ethanol extract of betel leaves gained as much as 20 grams with $100 \%$ concentration. Afterwards, extract ethanol of betel leaves $20 \%, 15 \%$, $10 \%, 5 \%$ and $1 \%$ made in $\mathrm{NaCMC}$.

\section{Treatment}

There are seven treatment groups which each group consisting of five mice. The division of the treatment groups: (1) Group A, the sample is not given treatment (negative control); (2) Group B, the sample dipped into Feracrylum 1\% (positive control); (3) Group $\mathrm{C}$, the sample dipped into ethanol extract of betel leaves 1\%; (4) Group D, the sample dipped into ethanol extract betel leaves 5\%; (5) Group E, the sample dipped into ethanol extract of betel leaves 10\%; (6) Group F, the sample dipped into ethanol extract of betel leaves 15\%; (7) Group G, the sample dipped into ethanol extract of betel leaves $20 \%$.

\section{Effects haemostatics test of betel green leaves extract}

Mice from all treatment groups were injected intravenous heparin 14.56 UI using a one cc syringe toensure that the hemostatic effects of ethanol extract of green betel leaf are not from the effects of the body's hemostatic mice. Mice's tail at diameter 3 and $4 \mathrm{~mm}$ determined using the ruler and marked. Mice's tail which will be cut, sterilized using a cotton swab moistened with $70 \%$ ethanol. Then performed topical anesthesia with ethyl chloride spray using cotton. Mice's tail in diameter of $3 \mathrm{~mm}$ cut using minor surgery scissor in all treatment groups and control groups, respectively. Furthermore, mice were positioned on the filter paper. Bleeding time measured with a stopwatch since the first blood dripping blood until completely stopped dripping on the filter paper to know a bleeding time before treatment. After that, mice 's tail in diameter of $4 \mathrm{~mm}$ cut using minor surgery scissors in all treatment groups and control groups, respectively. Then, treatment groups and positive control group dipped into extract ethanol of betel leaves with the concentration of $1 \%, 5 \%, 10 \%, 15 \%, 20 \%$, and Feracrylum $1 \%$ for 5 seconds. On the negative control group was given no treatment, but only allowed to stand for 5 seconds. Mice's tail were positioned on the filter paper. Bleeding time measured with a stopwatch since the first blood dripped on the filter paper to completely stop blood dripping and bleeding time were recorded to know bleeding time after treatment.

\section{RESULTS AND DISCUSSION}

An experimental study to determine the minimum concentration of ethanol extract of betel leaves which can shorten the hemorrhage has been done in January until November 2016 at the Laboratory of Biochemistry Medical Faculty of Sriwijaya University. The subjects were 35 male mice were divided into seven groups and injected intravenous heparin as much as 14.56 UI. Sterilization procedures, cutting the tail in a diameter of $3 \mathrm{~mm}$, counting the bleeding time before treatment, cutting the tail on the diameter of $4 \mathrm{~mm}$, the treatment, and counting bleeding time after treatment is done 30 minutes after injection of heparin. This is because heparin initially worked on for 20-60 minutes after injected. Intravenous heparin injection is done to ensure that the hemostatic effects of ethanol extract of betel leaves are not from hemostatic effects that come from the body of mice (Gray, Hogwood \& Mulloy, 2012).

Shapiro-Wilk normality test is performed to determine data distribution of bleeding time. The test results showed that $p>0.05$. This means that the data are normally distributed. Levene's test of homogeneity is done with the results $\mathrm{p}>0.05(\mathrm{p}=0.067)$. This means that the data homogeneous. Normality and homogeneity test of data showed that the data was normal and homogeneous then continued data analysis using parametric tests.

Hemostatic effect of ethanol extract of betel leaves in mice known through the bleeding time of mice before and after treatment. Data of mice's bleeding time before and after treatment in the negative control group (without being offered treatment), positive control (feracrylum 1\%), ethanol extract of betel leaves with the concentration of $1 \%, 5 \%, 10 \%, 15 \%$, and $20 \%$ can be seen in Table 1. 
Tabel 1. Average of bleeding time from each group at before and after treatment

\begin{tabular}{lccr}
\hline \multirow{2}{*}{\multicolumn{1}{c}{ Groups }} & \multicolumn{2}{c}{ Average of bleeding time (second) } & $P$ \\
\cline { 2 - 3 } & Before & After & Value \\
\hline Negative control & $32.5 \pm 17.311$ & $361.25 \pm 16.520$ & 0.089 \\
Positive control & $336.75 \pm 13.889$ & $170.5 \pm 4.203$ & 0.000 \\
Ethanol extract of betel leaves 1\% & $318.5 \pm 15.330$ & $182.75 \pm 4.573$ & 0.000 \\
Ethanol extract of betel leaves 5\% & $323.5 \pm 17.020$ & $139 \pm 4.163$ & 0.000 \\
Ethanol extract of betel leaves 10\% & $355.5 \pm 17.937$ & $108 \pm 5.852$ & 0.000 \\
Ethanol extract of betel leaves 15\% & $335 \pm 22.286$ & $81 \pm 6.055$ & 0.000 \\
Ethanol extract of betel leaves 20\% & $340 \pm 22.847$ & $53.75 \pm 9.743$ & 0.000 \\
\hline
\end{tabular}

Paired $t$-test, significant if $p<0.05$.

The hemostatic effect of ethanol extract of betel leaves in mice known through bleeding time mice before and after treatment. Before treatment, all mice was injected with intravenous heparin. Heparin is one type of anticoagulant medication to prevent blood clotting by inhibiting the formation of blood clotting factors, then increase the effect of antithrombin III. The increasing antithrombin III can cause the inactivation of thrombin, thus preventing the conversion of fibrinogen into fibrin (Gray et al., 2012).

Table 1 shows that the average bleeding time of mice before treatment, the negative control group is 325.5 seconds, positive control group is 336.75 seconds, ethanol extract of betel leaves $1 \%$ group is 318.5 seconds, ethanol extract of betel leaves $5 \%$ group is 323.5 seconds, ethanol extract of betel leaves $10 \%$ group is 355.5 , ethanol extract of betel leaves $15 \%$ group is 335 seconds, and ethanol extract of betel leaves $20 \%$ group is 340 seconds. The results of this study are consistent with the research conducted by Greene, Schivis, Hoellriegl, Poncz, and Muchitsch (2010). Greene et al. (2010) stated that the bleeding time of normal mice is 51-62 seconds. Heparin which injected intravenously to provided enough hemorrhage effect demonstrated with average bleeding time is six times greater than normal bleeding time. The aim of heparin's injection in this study was to eliminate the bias of clotting factors in the body of mice (Greene et al., 2010; Gray et al., 2012).

Paired t-test conducted between groups before the treatment group after treatment. Paired t-test is performed to determine an average of bleeding time before and after treatment. Data paired t-test results can be seen in Table 1.
Table 1 shows a decrease in the average bleeding time with probability $p$ $<0.05$ in the positive control group and the treatment group, while in the negative control group not seen a decrease in the average bleeding time because of the value of the resulting probability $\mathrm{p}>0.05$. This means that there are differences in the average time of hemorrhage in the positive control group and the treatment group before and after treatment rendered while in the negative control group there was no difference in the average time difference before and after treatment.

Table 1 shows that after treatment's bleeding time of all groups of mice are shorter compared to before treatment's bleeding time, except in the negative control group. This means that the ethanol extract of betel leaves $1 \%, 5 \%, 10 \%, 15 \%$, and $20 \%$ can shorten the bleeding time. The reduction of average bleeding time before and after treatment in the group of ethanol extract of betel leaves $1 \%$, $5 \%, 10 \%, 15 \%$, and $20 \%$ were statistically significant with $\mathrm{p}=0.000$. The results are consistent with Tedjasulaksana (2013) research, which reported the hemostatic effects of ethanol extract of betel leaves with $100 \%$ concentration. The study also reinforces Chakroborty (2011) research that stated betel leaves extract has a hemostatic effect.

One way ANOVA test is performed to determine the difference of average bleeding time between groups after being treated. The results one way ANOVA test shows that $p$ value $=0.000$, which means that there is a significant difference in the average bleeding time between groups after given treatment. Post hoc test was performed using the least significance difference (LSD) with the aim to determine the influence of each treatment group towards average bleeding time. Post hoc test results can be seen in Table 2. 
Tabel 2. Comparative Analysis of After Treatment Bleeding Time Among Groups

\begin{tabular}{cccccccc}
\hline P value & $\begin{array}{c}\text { Negative } \\
\text { control }\end{array}$ & $\begin{array}{c}\text { Positive } \\
\text { control }\end{array}$ & $\begin{array}{c}\text { Treatment } \\
1\end{array}$ & $\begin{array}{c}\text { Treatment } \\
2\end{array}$ & $\begin{array}{c}\text { Treatment } \\
3\end{array}$ & $\begin{array}{c}\text { Treatment } \\
4\end{array}$ & Treatment 5 \\
\hline $\begin{array}{c}\text { Negative } \\
\text { control }\end{array}$ & & 0.000 & 0.000 & 0.000 & 0.000 & 0.000 & 0.000 \\
$\begin{array}{c}\text { Positive } \\
\text { control }\end{array}$ & 0.000 & & 0.052 & 0.000 & 0.000 & 0.000 & 0.000 \\
$\begin{array}{c}\text { Treatment } \\
\quad 1\end{array}$ & 0.000 & 0.052 & & 0.000 & 0.000 & 0.000 & 0.000 \\
$\begin{array}{c}\text { Treatment } \\
2\end{array}$ & 0.000 & 0.000 & 0.000 & & 0.000 & 0.000 & 0.000 \\
$\begin{array}{c}\text { Treatment } \\
3\end{array}$ & 0.000 & 0.000 & 0.000 & 0.000 & & 0.000 & 0.000 \\
$\begin{array}{c}\text { Treatment } \\
4\end{array}$ & 0.000 & 0.000 & 0.000 & 0.000 & 0.000 & & 0.000 \\
$\begin{array}{c}\text { Treatment } \\
5\end{array}$ & 0.000 & 0.000 & 0.000 & 0.000 & 0.000 & 0.000 & \\
\hline
\end{tabular}

Post hoc test least significance difference, significant if $p<0,05$.

Table 2 shows that there are significant differences in after treatment bleeding time among groups with $\mathrm{p}<0.05$ in all groups. However, there are no significant differences in the positive control group and the treatment group 1 . It is showed by the p value $=0.052$.

The hemostatic effect produced by the ethanol extract of betel leaves is suspected because of the content of tannins and saponins. Tannins and saponins have astringent effect that can assist the process of hemostasis by reducing the secretion and capillary permeability, contraction of space between cells, hardening of the endothelium of capillaries, contraction of space between cells, and forms a protective layer so that the superficial layer of cells will tighten and shrink then cause local vasoconstriction of capillaries (Chandra Tripathi, Verma, Singh, Chaudhary \& Roshan, 2011; Pradhan, Suri, \& Biswasroy, 2013; Barbosa, 2014). Tannins also will accelerate the release of protein from cells and precipitate proteins from the blood so as to reduce the amount of albumin in the blood (Bele et al., 2010, Ashok \& Upadhyaya, 2012; Barbosa, 2014). Reduction of albumin in the blood will result in increased synthesis of thromboxane A2 and facilitate platelet ADP issued. Thromboxane A2 and ADP activates platelets and causes adjacent platelets attached to the original that has been active. This led to increased platelet aggregation to form a platelet plug (Mohan, Gupta, \& Shenoy 2011; Barbosa, 2014). Additionally, saponins can bind to proteins in the blood by forming webs as traps for red blood cells, leukocytes, and platelets that clog capillary bleeding (Chandra et al., 2011, Mohan et al., 2011; Barbosa, 2014).

The other content of the ethanol extract of betel leaves that suspected as a hemostatic agent is a flavonoid. Flavonoids are pigments which widespread in the form glikon and aglycone compounds that can inhibit bleeding (Periyanayagam et al., 2012; Bhalerao et al., 2013). Other mechanisms of flavonoids in stopping the bleeding is vasoconstriction (Fine et al., 2013; Nirmala \& Kumari, 2015).

The use feracrylum $1 \%$ as a positive control because feracrylum $1 \%$ can stop the bleeding and widely used by dentists (Lahoti et al., 2010; Singh, 2016). Mechanism of action of feracrylum $1 \%$ is by inhibiting the coagulation phase in the process of hemostasis (Singh, 2016). This is consistent with research showing that the average time of bleeding before and after treatment in the positive control group was statistically significant with $\mathrm{p}<0.05$.

Table 2 shows that the difference of after treatment bleeding time among groups was statistically significant with $p<0.05$ in all groups, except in the positive control group and the group given ethanol extract of betel leaves $1 \%(\mathrm{p}=0.052)$.

This means that ethanol extracts of betel leaves with a concentration of $5 \%, 10 \%$, $15 \%$, and $20 \%$ has better ability to shorten the bleeding time compared to ethanol extract of betel leaves $1 \%$ and feracrylum $1 \%$, which suspected contains tannins, saponins, and flavonoids (Bhalerao et al., 2013). While the 
hemostatic effects of ethanol extract of betel leaves $1 \%$ and feracrylum 1\% towards mice's bleeding is almost the same.

Based on research and data analysis that has been done, the ethanol extract of betel leaves with concentrations ranging from 5\%, $10 \%, 15 \%$, and $20 \%$ have a hemostatic effect on mice's bleeding. This means that the minimum concentration of the ethanol extract of betel leaves which can shorten the bleeding time of mice was $5 \%$. Based on this study, low concentration of ethanol extract of betel leaves has potential as a drug. A plant had potential as a medicinal plant is when at the concentration below $20 \%$ already had expected teraupetic effect. At low concentration, beside had an economic benefits, it is also had a low possibility to cause a side effect (Chandra et al., 2011; Mohan et al., 2011; Bhalerao et al., 2013).

\section{CONCLUSION}

The ethanol extract of betel leaves has a hemostatic effect. The enhancement of ethanol extract of betel leaves concentration leads to better hemostatic effect. Minimal concentration of ethanol extract of betel leaves which has a hemostatic effect was $5 \%$.

\section{REFERENCES}

Ashok, P. K., \& Upadhyaya, K. (2012) Tannins are astrigent. Journal of Pharmacognosy and Phytochemistry, l(3), 45-50.

Barbosa, E. A. (2014). An overview on the biological and pharmacological activities of aaponins. International Journal of Pharmacy and Pharmaceutical Sciences, 6(8), 47-50.

Bele, A. A., Jadhav, V. M., \& Kadam, V.J. (2010). Potential of tannins: A review. Asian Journal of Plant Sciences, 9(4), 209-214.

Bhalerao, S. A., Verma, D. R., Gavankar, R. V., Teli, N. C., Rane, Y. Y. ..., Trikannad, A.(2013). Research and Review: Phytochemistry, pharmacological profile and therapeutic uses of Piper Betle, Linn. Journal of Pharmacognosy and Phytochemistry, 1(5), 12-18.

Bissa, S, Songara, D, \& Bohra, A. (2007). Traditions in oral hygiene: Chewing of betel (Piper betle, Linn.) leaves. Current Science, 92(1), 26-8.
Borle, R. M. (2014). Textbook of oral and maxillofacial surgery. New Delhi: Jaypee Brothers Medical Publishers.

Chakraborty, B. S. (2011). Antimicrobial, antioxidative and antihemolytic activity of Piper betel leaf extracts. International Journal of Pharmacy and Pharmaceutical Sciences, 3(3), 192199.

Chandra, V., Tripathi, S., Verma, N.K., Singh, D. P., Chaudhary, S. K., \& Roshan, A. (2011). Piper betle: Phytochemistry, traditional use and pharmacological activity - a review. Chinese Journal of Integrative Medicine, 4(4), 216-223.

Grace, A. S. (2010). The hemostatic effect of A. vulgaris extract in traumatic bleeding on Mus musculus. Asia Pacific Dental Students Journal, 1(2), 174-183.

Gray, E., Hogwood, J. \& Mulloy, B. (2012). The anticoagulant and antithrombotic mechanisms of heparin. Handbook of Experimental Pharmacology, 207, 43-61

Greene, T. K., Schiviz, A., Hoellriegl, W., Poncz, M., \& Muchitsch, E. M. (2010). Towards a standardization of the murine tail bleeding model. Journal of Thrombosis and Haemostasis, 8(1), 2820-2802.

Lahoti, K., Aggarwal, G., Shashi, S., \& Laddha, A. (2010). Hemostasis during hypospadias surgery via topical application of feracrylum citrate: a randomized prospective study. Journal of Indian Association of Pediatric Surgeons, 15(3), 87-89.

Mohan, M., Gupta, A., \& Shenoy, V. (2011). Pharmacological agents in dentistry: a review. British Journal of Pharmaceutical Research. 5(3), 66-87.

Nirmala, B. R, \& Kumari, S. O. (2015). Phytochemical analysis of Piper Betle leaf extract. World Journal of Pharmacy and Pharmaceutical Sciences, 4(1), 699703.

Periyanayagam, K., Jagadeesan, M., Kavimani, S., \& Vetriselvan. (2012). Pharmacognostical and physicochemical profile of the leaves of Piper betle, Linn -valuable assessment of it's quality. Asian Pacific Journal of Tropical Biomedicine, 2(5), 31-39.

Pradhan, D., Suri, K. A., \& Biswasroy, P. (2013). Golden heart of the nature: 
Piper betle L. Journal of Pharmacognosy and Phytochemistry, 1(6),147-167.

Rupa, S., Banik, \& Jayanta, K. (2013). A Review on Piper betle Leaf. International Journal of Pharmaceutical Sciences and Research, 4(12) 45-49.

Sam, S. (2008). Hemorrhagic complications of anticoagulant and thrombolytic treatment. Chest, 13(3), 133-147.
Singh, K. (2016). Role of local instillation of one percent feracrylum and hemocogulase on woundhealing. International Jornal of Research in Medical Science, 4(1), 169-176.

Tedjasulaksana, R. (2013). Ekstrak etilasetat dan etanol daun sirih (Piper betle, L) dapat memperpendek waktu perdarahan mencit (Mus musculus). Jurnal Kesehatan Gigi, 1(1), 32-39. 